\title{
Epistemological Contributions of Toulmin's Argumentative Model in Scientific Education
}

\author{
Tiago Clarimundo Ramos ${ }^{1}$, Marcos Fernandes Sobrinho ${ }^{2,3,4}$
}

${ }^{1}$ Federal Institute Goiano (IF Goiano), Rio Verde, Brazil

${ }^{2}$ Postgraduate Program in Professional Technology Education, Federal Institute Goiano (ProfEPT/IFGoiano), Urutaí, Brazil ${ }^{3}$ Postgraduate Program in Education for Science of the University of the State of São Paulo (PPGEpC/FC/Unesp), Bauru, Brazil ${ }^{4}$ Postgraduate Program in Organizational Management of the Federal University of Catalão (PPGGO/UFCat), Catalão, Brazil Email: tiago.ramos@ifgoiano.edu.br, marcos.fernandes@ifgoiano.edu.br

How to cite this paper: Ramos, T. C., \& Sobrinho, M. F. (2018). Epistemological Contributions of Toulmin's Argumentative Model in Scientific Education. Creative Education, 9, 559-566.

https://doi.org/10.4236/ce.2018.94039

Received: November 3, 2017

Accepted: April 9, 2018

Published: April 12, 2018

Copyright $\odot 2018$ by authors and Scientific Research Publishing Inc. This work is licensed under the Creative Commons Attribution International License (CC BY 4.0).

http://creativecommons.org/licenses/by/4.0/

\begin{abstract}
On the basis of a theoretical study, the objective of this article is to analyze questions around the scientific rationality, with an indication of the potentialities of Toulmin's model of argument that can subsidize the confrontation of the problem of scientific education practices landmarked of an absolute and neutral science. The use of this argumentative model is legitimated, mainly, with the possibility of refutation as a way of demonstrating that the theoretical knowledge is provisional conjectures. Thus, it is emphasized that any conception of science linked to the activity of isolated individuals in search of truth is not resonant even with social reality itself.
\end{abstract}

\section{Keywords}

Epistemological Debate, Scientific Rationality, Toulmin’s Argumentative Model, Refutation, Scientific Education

\section{Teaching and Its Implicit Epistemological Bases against the Inductivists}

The internal characteristics and modes of production of scientific knowledge can hardly be reduced to a single subject. Indeed, in large groups, researchers seek, through their studies, to institute different ways of problematizing and investigating reality. In this direction, historically, there has been an extensive debate about what science is, that connects to a remarkable preoccupation with singularities of the scientific development that can distinguish the Sciences from other so-called non-scientific activities (Peci \& Alcadipani, 2006).

Particularly in the field of teaching, several authors (Cawthron \& Rowell, 
1978; Hodson, 1985; Silveira, 1996) have recognized that every practice is always permeated by an implicit epistemological basis. In our schools, however, a predominantly inductivist scientific education still persists: "[...] The observation is the source and function of knowledge. All knowledge derives directly or indirectly from sensitive experience (sensations and perceptions); before we can make any statement about the world, we must have had sensory experiences. Scientific knowledge is obtained from phenomena (what is observed), applying the rules of the scientific method (an algorithmic procedure that applied to observations produces generalizations, laws, scientific theories). Knowledge is an inductive synthesis of the observed, the experienced" (Silveira, 1996: p. 225).

This epistemological conception also appears in materials aimed at experimentation in the teaching of Science. Nevertheless, whether by demonstration, verification and/or investigation (de Araújo \& dos S. Abib, 2003), the student ends up being induced to accept that the laws that govern nature are necessarily hidden in data, leaving only a task to confirm, a scientific (or principle) concept, through experience.

Another practice that seems to reinforce induction is the so-called "learning by discovery" (Cleminson, 1990); in which a conceptual formation is recommended by rigorous conduction of sequences and/or didactic itineraries ways that aim to help students in overcoming their learning difficulties. If on one hand, induction deals with several particular cases without being able to make a theory true, on the other hand, deduction can falsify it with only one case, due to its asymmetrical logic from the general to the particular, and that way, getting closer to the truth (Fernandes-Sobrinho, Gonçalves, \& Fernandes, 2017).

Apart from these notes, it is argued that teaching Science in a way to consider scientific knowledge as a body of absolute truths is drastically opposed to an epistemological conception of critical rationalism (Popper, 1959). Just like it will be discussed later, it is not enough to elaborate a theory, but it must put it to the test. This way, the critical rationalism is defended, different from an average critical attitude, since the search for a truth must rely on the application of a falsificationist model.

It is within this range that, in the condition of a theoretical study, it aims to broaden the discussion about different visions of scientific demarcation, based both on authors in the field of Sciences of Nature as Social Sciences, with an analytical outcome that supports the potentialities of the use of the argumentative model of Toulmin in scientific education.

\section{From Inductive Logic to Critical Rationalism}

In a pioneering empiricist view, in proposing a process of construction of scientific knowledge based on the observation of phenomena and induction, Bacon (1973) had a concern to break, above all, with the syllogistic reasoning of the Aristotelian logic. For the author, all human knowledge comes from scientific experimentation. According to his inductive method, presented in the classic 
work of Novum Organum, from a set of rules, with adequate manipulation, it would be impossible as a researcher not to generate new knowledge.

However, in commenting on Baconian epistemology, (Oliva, 1990a) explains that the researcher would have to eliminate all idola from his mindso that his soul would be ready to build a new knowledge from the perceptions of nature. In this sense, interpretative and creativity would play, at most, residual roles in the process of producing theories.

For Schlick (1975), in the logical empiricism of the Vienna Circle, ideal forms of doing science should be based on verificationism and inductivism. In this neoempirist view, only the data was real. A proposition would only make sense when it really could be verified. According to (Oliva, 1990b), this verificationist criterion of scientificity, however, could only be sustained as a denunciation of purely ideological speeches; and not true as a reconstruction of "meaning that statements should display to assume scientific status" (Oliva, 1990b: p. 36).

Thus, it is in this context that Popper (1959) constructed a strong criticism both to verificationism and to inductive logic: [...] it is far from obvious, from a logical point of view, that there is justification in inferring universal statements from singular statements, not related to how numerous these are; so, any conclusion obtained that way can always be false; regardless of how many white swans we can observe, this does not justify the conclusion that all swans are white (Popper, 1959: p. 27).

As an exist for the problem of induction, Popper (1959) then suggested a hypothetical-deductive model, marked by the critical rationalism. In this proposal, for a theory to assume scientific status it should be subjected to falsifiability. This way, scientificity was linked to the risk of exposing theory to testing. For the author, progress in science is sustained by refutation. Just as, in science, there can be no definitive statements that are insusceptible to the test.

In this perspective, the most striking feature of science refers to rationality in the search and expansion of knowledge. Scientists not only elaborate the theories but also must put them to the test. This concern must be expressed both in the possibility of a critical discussion of different possibilities of explanation as well as in the attitude of change (or revision) in the theory, always with well-defined criteria to enable comparability and choice. Thus, the scientific knowledge can never be demonstrated as an absolute truth; it is always a provisional conjecture and subject to reformulation.

\section{A Debate on Scientific Rationality}

Although Popper had stressed the importance of investing in bold hypotheses, always susceptible to refutation, Kuhn (1996) suggested other extra-scientific elements that could interfere with the scientific activity. When introducing the idea of "normal science", the author emphasized that, in general, the activities carried out by scientists occur within established paradigms; and so there would be no pretension to produce major innovations. The researcher would be more 
concerned with carrying out his studies through the articulation of phenomena and established theories; it is as if these studies are reduced only to the resolution of some "puzzles".

In the Kuhnian metaphor of "puzzles," reality would be a bunch of pieces that, when properly put together, would give aninsight into how nature worked. However, even before you put the "puzzle" together, you already know what to expect. With this understanding, the scientific community would already have an idea of how the world behaves. From there, the research would focus only on the proof and/or improvement of a knowledge. Whereas new theories are only evoked when anomalies appear in the relation of the current theory of nature. On the other hand, the new theory must prove successful and, at some point, allow different predictions from those derived from its predecessor.

By using historiography, Kuhn (1996) warned of a non-cumulative scientific development marked by episodes of scientific revolutions, in which an older paradigm can be replaced (partly or even totally) by a new one. However, to establish a crisis in a paradigm, the anomalies in scientific theories must always lead to a sense of faulty functioning that is a prerequisite for a revolution. As the researcher is governed by a paradigm, this limits his vision to the new. This way, it is foreseeable that at first, when anomalies arise, the researcher tries to make adjustments to save a scientific theory. However, if this is not feasible and the malfunctioning persists, your choice will certainly be the change. In addition, this adoption of the new paradigm often occurs for reasons that are at the margin of science.

In Popper's point of view, however, the main danger of Kuhnian ideas lies in attributing to science an image of extreme relativism and/or irrationalism. Similarly, for Lakatos (1979), the Kuhnian concept of "crisis" can lead to a true "contagious panic"; in which there is a scientific revolution without any rationality, known better as a matter of psychologism than science. According to the author, there are no crucial experiments capable of instantly overturning a research program. A hasty scientist might even claim that his experience defeated a program; and parts of the scientific community may, quite precipitously, even accept the statement. But if a scientist of the defeated field presents a scientific explanation of the crucial experience in the program allegedly defeated a few years later, the title can be removed and experience can turn from a defeat into a new victory for the program.

In this respect, the progress of scientific knowledge would depend on the existence of competing programs. In lakatosian epistemology, "experiments simply do not overrule theories, no theory forbids a specifiable state of affairs in advance. Only the series of isolates theories and non-theories can be classified as scientific or non-scientific" (Lakatos, 1979: p. 215). In this sense, note that both Lakatos (1979) and Popper (1979) defended rationalism, opposing any ideas of scientific changes governed by irrational mechanisms.

However, the Popperian attitude of subjecting any theoretical knowledge to criticism is translated, above all, into a commitment to fundamental characteris- 
tics of scientific development opposed to dogmatism. Just as if a theory is being criticized, what it is actually questioned is its claim to support, or to what extent it is able to respond to the issues of its responsibility. In this sense, a rational choice must therefore always presuppose a preference for the theory with higher corroborated content.

\section{The Argumentative Model of Toulmin in the Scientific Education}

In a scientific education that intends to broaden the discussions about science, rationality constitutes an element that would certainly make it impossible to comprehend the valuation of the scientific enterprise (Aguiar Júnior, 2016). According to Jiménez-Aleixandre (2008), this learning about science should give the opportunity, mainly, to the commitment of students with the argument in the construction of explanations and critical evaluations of the pieces of evidence. It is from this perspective that the proposition of the use of argumentation in scientific education, according to Toulmin's model (2006), as a strategy for deepening the non-dogmatic and provisional dimension of scientific knowledge.

In the book entitled The Use of Argument, Toulmin (2006) proposes that the order of justification of a conclusion must be composed of a series of phases. The presentation of a problem must appear at the beginning of the justification process, and this should be done by asking a clear question. Moreover, it is accepted that the triggering of scientific argumentation in educational contexts must first establish a claim of interest, and then worry about its justification. In addition, the questions should not contain contradiction and/or contextual incongruity; since questions built on an intelligible basis are always at risk of not being well comprehended.

Thus, starting from an initial idea of a problem up to the conclusion there are some elements that need to emerge along the progress of the argumentation in order to demonstrate that taking the data is legitimate to conclude (Figure 1). Therefore, as defined by Toulmin (2006), this step from data (D) to the conclusion $(C)$ must contain, minimally, a guarantee $(G)$, which translates into the implicit patterns (or canons) of the argument.

In order that the use of Toulmin's argumentative model in teaching does not reinforce a purely inductive perspective, it is essential to introduce problematizations that can actually involve subjects with the construction of explanations for phenomena and/or problems of Science (Mendonça \& Justi, 2013). However, it is accepted that the confrontation of the problem of "inductivism" in the

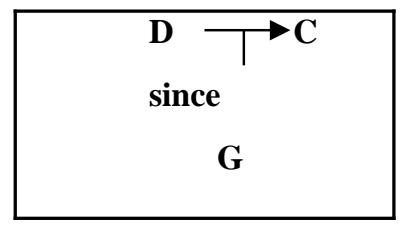

Figure 1. Minimum structure of an argument. 
ching of sciences, requires advancing in the construction of an argument that goes beyond the minimal structure suggested by Toulmin.

In reality, there is a vast class of arguments that can be expressed in the form: D, G, then C; but as Toulmin (2006) describes, three more elements must emerge from a complete argumentation (Figure 2): 1) the modal qualifier (Q) which manifests itself in the form of an adverb with the indicative of the force of the guarantee (for example, certainly, presumably, etc.); 2) the support (A) for the guarantee that offers more categorical contributions for a better understanding of the reasons for argument; and 3) the rebuttal (R) used to indicate the circumstances in which the general authority of the guarantee does not apply.

It should be considered that scientific knowledge does not emerge only from the data, but from the bold ideas (Popper, 1959) that must be constantly subjected to criticism. In this sense, to use Toulmin's argumentative model in its expanded form in the teaching of Sciences implies, above all, to assume the possibility of refutation as a way of indicating that scientific knowledge is always temporary and not dogmatic. It is in the criticism that there must be any scientific objectivity (Popper, 2006). In short, a Science Education that fails to contemplate the circumstances in which knowledge can be refuted somehow fails to represent the true essence of scientific development.

\section{Final Considerations}

The epistemological debate being taken from the authors brought in, as well as the questions surrounding the scientific rationality raised in this work corroborate, to a large extent, to subsidize the confrontation of the problematic of scientific education practices that mark the absolute and neutral science.

In particular, in the study of Science, there is a need to stimulate an argument based on the Toulmin (2006) model, in its expanded form, in order to take the students to refute explanations often presented as dogmatic. In this sense, in agreement with Popperian's optics, it is suggested that the theoretical knowledge is treated in scientific education always as conjectures.

In a Science Education perspective, a particular epistemological approach must always be distinctively special in the construction and realization of teaching-learning processes, depending on the way in which the abstract is related to the real and the concrete. Faced with this, the question arises: where can this

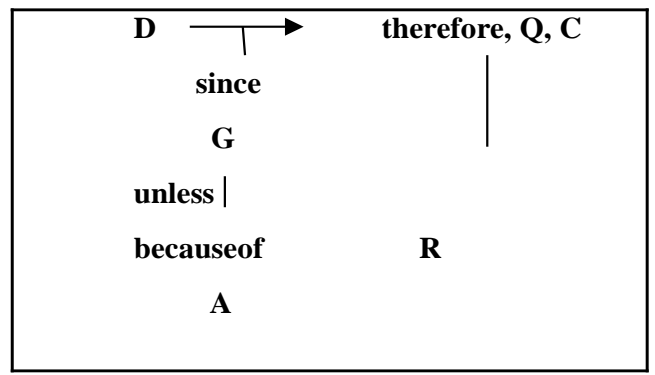

Figure 2. A complete structure of an argument. 
non-dogmatic conception of science in education lead us? The answer to this questioning is certainly permeated by changes in the way of thinking, with disenchantment and awareness of a less pretentious science. It is necessary to discern that in science there is no absolute truth, independent of the area so that the construction of knowledge itself abdicates dogmatic assumptions precisely in favor of the right to think.

Therefore, it is important to deepen the problematization of the contents of Sciences in order to rescue the construction of arguments that can contemplate the different components of the Toulmin model, with the real commitment of the educators to develop with their students the recognition that all scientific knowledge is temporary and not dogmatic. This problematization, however, must never be neglected in relation to the refutation of (somewhat misleading) deterministic technocratic speeches that proclaim a scientific and technological innovation that certainly leads to the solution of all problems, including social problems.

It should be noted that "more and more it makes less sense to think of scientific knowledge out of context of society and current technological development" (Praia \& Cachapuz, 2005: p. 191). Any conception of science linked to the activity of separated individuals in search of truth is not resonant with the social reality itself (Dagnino, 2008), since it has been increasingly driven by the demands of industrial development and unstoppable consumption imposed on the process of modernization.

In summary, the use of Toulmin's model in scientific education is indicated in this article as a viable alternative that can be very useful to the development of the student's argumentation, especially in order to signal to the possibility of criticizing and confront different explanations for the problems, with the return of the formation of more democratic and sustainable values, often overlooked in the field of teaching and learning in Sciences.

\section{Acknowledgements}

The present work had financial support from Instituto Federal Goiano. The second author has a scholarship of the National Postdoctorate Program of the Coordination for the Improvement of Higher Education Personnel (PNPD/ CAPES).

\section{References}

Aguiar Júnior, O. (2016). O papel do construtivismo na pesquisa em ensino de ciências. Investigações em ensino de ciências, 3, 107-120.

Bacon, F. (1973). Novumorganum ou verdadeiras indicações acerca da interpretação da natureza. Portal periódicos CAPES. Domínio Público.: Créditos da digitalização: Membros do grupo de discussão Acrópolis (Filosofia). http://br.egroups.com/group/acropolis/

Cawthron, E. R., \& Rowell, J. A. (1978). Epistemology and Science Education. Epistemology and Science Education, 5, 31-59. https://doi.org/10.1080/03057267808559856 
Cleminson, A. (1990). Establishing an Epistemological Base for Science Teaching in the Light of Contemporary Notions of the Nature of Science and of How Children Learn Science. Journal of Research in Science Teaching, 27, 429-445. https://doi.org/10.1002/tea.3660270504

Dagnino, R. (2008). Neutralidade da ciência e determinismo tecnológico: Um debate sobre a tecnociência. Campinas: Unicamp.

de Araújo, M. S. T., \& dos S. Abib, M. L. V. (2003). Atividades experimentais no ensino de física: Diferentes enfoques, diferentes finalidades. Revista Brasileira de Ensino de Física, 25, 176-194. https://doi.org/10.1590/S1806-11172003000200007

Fernandes-Sobrinho, M. F., Gonçalves, E. A., \& Fernandes, P. S. R. (2017). Percurso e diversidade epistemológica da pesquisa em educação: Tensionamentos e possibilidades. Cadernos de Pesquisa, 23, 81-91. https://doi.org/10.18764/2178-2229.v.23n.especial/p81-91

Hodson, D. (1985). Philosophy of Science, Science and Science Education. Studies in Science Education, 12, 25-57. https://doi.org/10.1080/03057268508559922

Jiménez-Aleixandre, M. P. (2008). Designing Argumentation in Learning Environments. In S. Erduran, \& M. P. Jiménez-Aleixandre (Eds.), Argumentation in Science Education: Perspectives from Classroom-Based Research (pp. 91-115). Dordrecht: Springer.

Kuhn, T. S. (1996). A estrutura das revoluções científicas (4th ed.). São Paulo: Perspectiva.

Lakatos, I. (1979). O falseamento e a metodologia dos programas de pesquisa científica. In I. Lakatos, \& A. Musgrave (Eds.), A crítica e o desenvolvimento do conhecimento (pp. 109-243). São Paulo: Cultrix.

Mendonça, P. C., \& Justi, R. (2013). Ensino-aprendizagem de ciências e argumentação: Discussões e questões atuais. Revista Brasileira de Pesquisa em Educação em Ciências, 13, 187-216.

Oliva, A. (1990a). A hegemonia da concepção empirista de ciência a partir do novumorganon de Francis Bacon. In A. Oliva (Eds.), Epistemologia: A cientificidade em questão. São Paulo: Papirus.

Oliva, A. (1990b). Verificacionismo: Critério de cientificidade ou crítica à ideologia. In A. Oliva (Eds.), Epistemologia: A cientificidade em questão. São Paulo: Papirus.

Peci, A., \& Alcadipani, R. (2006). Demarcação científica: Uma reflexão crítica. Organizações \& Sociedade, 13, 145-161. https://doi.org/10.1590/S1984-92302006000100008

Popper, K. R. (1959). The Logic of Scientific Discovery. New York, NY: Basic Books.

Popper, K. R. (1979). A ciência normal e seus perigos. In I. Lakatos, \& A. Musgrave (Eds.), A crítica e o desenvolvimento do conhecimento (pp. 63-71). São Paulo: Cultrix.

Popper, K. R. (2006). A lógica das Ciências Sociais. In K. R. Popper (Eds.), Em busca de um mundo melhor. São Paulo: Martins Fontes.

Praia, J., \& Cachapuz, A. (2005). Ciência-Tecnologia-Sociedade: Um compromisso ético. Revista iberoamericana de ciencia tecnología y sociedad, 2, 173-194.

Schlick, M. (1975). Positivismo e realismo. In M. Schlick, R. Carnap, \& K. R. Popper (Eds.), Os pensadores (Vol. 44). São Paulo: Abril Cultural.

Silveira, F. L. da. (1996). A metodologia dos programas de pesquisa: A epistemologia de Imre Lakatos. Caderno Brasileiro de Ensino de Física, 13, 219-230.

Toulmin, S. E. (2006). Os usos do argumento (2nd ed.). São Paulo: Martins Fontes. 